\title{
HUBUNGAN KOMPETENSI GURU DENGAN KINERJA GURU
}

\author{
Rabukit Damanik \\ Dosen STKIP Budi Daya Binjai
}

\begin{abstract}
ABSTRAK
Guru adalah komponen yang sangat menentukan dalam keberhasilan suatu pendidikan. Hal ini memang wajar, sebab guru merupakan ujung tombak yang berhubungan langsung dengan siswa sebagai subjek dan objek belajar. Bagaimanapun bagus dan idealnya kurikulum pendidikan, bagaimana lengkapnya sarana dan prasarana pendidikan dan bagaimana kuatnya antusias peserta didik, tanpa diimbangi dengan kemampuan guru, maka semuanya akan kurang bermakna.Tujuan penelitian ini adalah untuk mendeskripsikan korelasi kompetensi guru dengan kinerja guru. Metode penelitian yang digunakan dalam penelitian ini adalah metode kuantitatif jenis korelasi. Pupulasi penelitian ini adalah berjumlah 96 orang guru SMP Negeri di Kecamatan Percut Sie Tuan. Hasil Penelitian menunjukkan : terdapat hubungan yang signifikan antara kompetensi guru dengan kinerja guru. Koefisien Korelasi yang diperoleh adalah 0,603 dengan level signifikansi alpha sebesar 0,05 .
\end{abstract}

\section{Kata Kunci : Kompetensi Guru dan Kinerja Guru}

\section{A. Pendahuluan}

Pendidikan adalah proses pelatihan dan pengembangan pengetahuan, keterampilan, fikiran, karakter dan seterusnya, khususnya lewat persekolahan formal (Sagala, 2007: 1) menyatakan pendidikan bukanlah semata-semata merupakan untuk dapat menyiapkan individu untuk dapat menyesuaikan dirinya dengan lingkungannya melainkan lebih diarahkan pada upaya pembentukan dan kesediaan melestarikan lingkungan dalam jalinan yang selaras. Keberhasilan pendidikan dapat dipengaruhi oleh banyak komponen. Adapun komponen-komponen yang mempengaruhi keberhasilan pendidikan adalah : (1) komponen guru, (2) komponen peserta didik, (3) komponen pengelolaan dan (4) komponen pembiayaan. Keempat faktor tersebut saling keterkaitan dan sangat menentukan maju mundurnya suatu pendidikan.

Guru adalah komponen yang sangat menentukan dalam keberhasilan suatu pendidikan. Hal ini memang wajar, sebab guru merupakan ujung tombak yang berhubungan langsung dengan siswa sebagai subjek dan objek belajar. Bagaimanapun bagus dan idealnya kurikulum pendidikan, bagaimana lengkapnya sarana dan prasarana pendidikan dan bagaimana kuatnya antusias peserta didik, tanpa diimbangi dengan kemampuan guru, maka semuanya akan kurang bermakna.

Untuk mencapai keberhasilan pendidikan dan meningatkan mutu pendidikan, guru harus memiliki kompetensi yang memadai. Adapun kompetensi yang harus dimiliki oleh guru adalah :
(1)
pedagogik,
(2) kompetensi 


\section{Jurnal Serunai Administrasi Pendidikan Vol 8, No. 2, Oktober 2019 e-ISSN 2620-9209}

kepribadian, (3) kompetensi profesional dan (4) kompetensi sosial. Guru yang telah memiliki kompensi yang telah ditetapkan diatas akan memiliki kinerja yang lebih baik dibandingkan dengan guru yang tidak memiliki kompetensi yang telah ditentukan diatas.Hal ini sesuai dengan apa yang dikemukakan oleh Amstrong (1998 : 15) yang menyatakan bahwa ada empat faktor yang mempengaruhi kinerja yaitu; (1) motivasi kerja, (2) kompetensi, (3) kejelasan dan penerimaan tugas dan (4)kesempatan untuk bekerja. Berdasarkan uraian diatas jelaslah bahwa kinerja guru dipengaruhi oleh kompetensi guru.

Untuk melihat kualitas seorang guru dan mengukur kinerja seorang guru kita dapat melihat kompentesi guru dan disiplin kerja seorang guru tersebut, sehingga kita dapat melihat sejauh mana pengaruh kompentesi guru dan disiplin kerja seorang guru terhadap kinerja guru di sekolah tempatnya bekerja. Kompetensi yang dimilki oleh setiap guru akan menunjukkan kualitas guru dalam mengajar. Kompetensi tersebut akan terwujud dalam kompetensi pedagogik, kompetensi sosial, kompetensi kepribadian, dan kompetensi profesional dalam menjalankan fungsinya sebagai guru. Artinya guru bukan saja harus pintar, tetapi juga harus pandai mentransfer ilmunya kepada peserta didik.

Menurut undang-undang republik indonesia Nomor 14 tahun 2005 tentang Guru dan Dosen, kompetensi adalah seperangkat pengetahuan, keterampilan dan perilaku yang harus dimiliki, dihayati dan dikuasai oleh guru atau dosen yang melaksanakan tugas keprofesionalannya. Guru mempunyai peranan penting dalam proses pembelajaran, sehingga seorang guru harus memiliki kompetensi profesional yang tinggi dan menghasilkan manusia yang memiliki SDM yang 4 tinggi. Guru yang profesional adalah guru yang memiliki empat kompetensi yaitu, kompetensi pedagogik, kompetensi kepribadian, kompetensi profesional, dan kompetensi social.

Namun saat ini pendidikan di Indonesia belum seperti yang diharapkan, karena lembagalembaga pendidikan belum mampu menghasilkan sumber daya manusia (SDM) yang berkualitas. Di lihat dari mahalnya biaya pendidikan dan mayoritas penduduk Indonesia paling banyak merupakan masyarakat ekonomi menengah kebawah. Sehingga naiknya biaya pendidikan tidak menyeimbangi dengan pendapatan yang diperoleh oleh mayoritas masyarakat. Sehingga menjadi salah satu faktor dari keterbelakangan pendidikan dalam masyarakat Indonesia. Namun, kondisi saat ini berbeda, IPTEK sudah semakin berkembang dan lapangan pekerjaan sudah terbuka luas bagi masyarakat. Berdasarkan fakta inilah peneliti tertarik untuk mengadakan penelitian yang bertujuan mencari hubungan antar variabel kompetensi guru dengan variabel kinerja guru SMP Negeri Sekecamatan Percut Sei Tuan Kabupaten Deli Serdang.

\section{B. Kajian Teoritik}

\section{Kinerja Guru}

Menurut Sagala (2007:179) kata kinerja dalam bahasa Indonesia adalah terjemahan dari kata dalam bahasa Inggris "Performance" yang berarti : (1) pekerjaan, perbuatan atau (2) penampilan, pertunjukan. Selanjutnya Rivai

$(2005: 13)$ 
mengemukakan performance/kinerja adalah hasil atau tingkat keberhasilan seseorang secara keseluruhan selama periode tertentu didalam melaksanakan tugas dibandingkan dengan berbagai kemungkinan, seperti standar hasil kerja target atau sasaran atau kriteria yang telah ditentukan terlebih dahulu dan disepakati bersama.

$$
\text { Menurut Gibson }
$$

mengemukakan bahwa kinerja merujuk kepada tingkat keberhasilan dalam melaksanakan tugas serta kemampuan untuk mencapai tujuan yang telah ditetapkan artinya kinerja dikatakan baik atau sukses jika tujuan yang diinginkaaan dapat tercapai dengan baik. Selanjutnya Wahyu Sumijo (2007) mengartikan kinerja secara kualitatif dan kuantitatif yang terukur dalam rangka membantu tercapainya tujuan kelompok dalam suatu unit kerja.

Pencapaian kinerja yang baik atau buruk bukan hanya dilihat dari hasil fisiknya saja, tetapi juga faktor non fisik seperti kesetiaan, disiplin, hubungan kerja sama, inisiatif, kepemimpinan, dan hal-hal khusus lain yang diperlukan yang berkaitan dengan tingkat pekerjaan yang dilakukan. Sejalan dengan asumsi tersebut, Mittchell (1982) menyatakan bahwa "kinerja merujuk pada hasil perilaku". Lebih rinci lagi dinyatakan bahwa "perbedaan kinerja terjadi karena adanya perbedaan individu dalam sifat-sifat kepribadian kemampuan, dan keterampilan". Kesimpulan dari pendapat tersebut dalam implikasi pengukuran kinerja didasarkan pada dua criteria, yaitu (1) menyelesaikan pekerjaan atas dasar syarat-syarat tertentu yang sudah ditetapkan, dan (2) mencapai sasaran tujuan pekerjaan dengan menunjukkan perilaku yang benar.

Menurut Usman (1984) menyatakan bahwa untuk dapat menunjukkan kinerja yang baik, individu harus memiliki kemampuan untuk bekerja, motivasi tinggi, dan juga kapasitas atau kecakapan (capacity) untuk berkinerja. Adapun kapasitas yang dimaksud antara lain mencakup kemampuan, bakat, keterampilan, latihan, peralatan dan tegnologi yang dapat digunakan untuk berkinerja. Sementara Mitrani, Daiziel, dan Fitt (1992) menyatakan terdapat empat faktor yang mempengaruhi kinerja yaitu : (1) sumber motivasi individual, (2) penetapan pekerjaan, (3) gaya manajemen, (4) iklim organisasi. Hal ini juga senada dengan pendapat Gannon (1979) yang menyatakan terdapat empat faktor yang mempengaruhi kinerja yaitu : (1) motivasi kerja, (2) kemampuan dan keterampilan kerja, (3) kejelasan dan penerimaan tugas, dan (4) kesempatan untuk berkinerja.

\section{Kompetensi Guru}

Kompetensi guru disebut juga kemampuan guru. Kompetensi yang harus dimiliki oleh seorang guru adalah sebagai berikut : (1) kompetensi pedagogik, (2). kompetensi kepribadian, (3) kompetensi sosial dan (4) kompetensi profesional (Sagala, 2009:31).

Menurut Slamet PH (2006) yang mengatakan kompetensi pedagogik terdiri dari 


\section{Jurnal Serunai Administrasi Pendidikan Vol 8, No. 2, Oktober 2019 e-ISSN 2620-9209}

Sub-Kompetensi (1) berkontribusi dalam pengembangan KTSP yang terkait dengan matapelajaran yang diajarkan; mengembangkan silabus matapelajaran berdasarkan standar kompetensi (SK) dan kompetensi dasar (KD); (3) merencanakan rencana pelaksanaan pembelajaran (RPP) berdasarkan silabus yang telah dikembangkan (4) merancang manajemen pembelajaran dan manajemen kelas; (5) melaksanakan pembelajaran yang pro-perubahan (aktif, kreatif, inovatif, eksperimentatif, efektif dan menyenangkan); (6) menilai hasil belajar peserta didik secara otentik; (7) membimbing peserta didik dalam berbagai aspek, misalnya: pelajaran, kepribadian bakat, minat, dan karir; dan (8). mengembangkan profesionalisme diri sebagai guru (Sagala, 2009 : 31).

Dari pandangan tersebut dapat ditegaskan kompetensi pedagogik merupakan kemampuan dalam pengelolaan peserta didik meliputi (1) pemahaman wawasan guru akan landasan dan filsatat pendidikan; (2) guru memahaman potensi dan keberagaman peserta didik, sehingga dapat didesain strategi pelayanan belajar sesuai keunikan masingmasing peserta didik; (3) guru mampu mengembangkan kurikulum/silabus baik dalam bentuk dokumen maupun implementasi dalam bentuk pengalaman belajar; (4) guru mampu menyusun rencana dan strategi pembelajaran berdasarkan standar kompetensi dan kompetensi dasar; (5) mampu melaksanakan pembelajaran yang mendidik dengan suasana dialogis dan interaktif. Sehingga pembelajaran menjadi aktif, inovatif, kreatif, efektif, dan menyenangkan (6) mampu melakukan evaluasi hasil belajar dengan memenuhi prosedur dan standar yang dipersyaratkan dan (7) mampu mengembangkan bakat dan minat peserta didik melalui kegiatan intrakurikuler dan ekstrakurikuler untuk mengaktualisasikan berbagai potensi yang dimilikinya (Sagala, $2009: 32$ ).

Kepribadian menurut Zakiah Daradjat (1980) disebut sebagai sesuatu yang abstrak, sukar dilihat secara nyata, hanya dapat diketahui lewat penampilan, tindakan, dan ucapan ketika menghadapi suatu persoalan, atau melalui atsarnya saja. Kepribadian mencakup semua unsur, baik fisik maupun psikis. Sehingga dapat diketahui bahwa setiap tindakan dan tingkah laku seseorang merupakan cerminan dari kepribadian seseorang. Apabila nilai kepribadian seseorang naik, maka akan naik pula kewibawaan orang tersebut. Tentu dasarnya adalah ilmu pengetahuan dan moral yang dimilikinya. Kepribadian akan turut menentukan apakah para guru dapat disebut sebagai pendidik yang baik atau sebaliknya, justru menjadi perusak anak didiknya (Sagala, 2009 : 33).

Dilihat dari aspek psikologi kompetensi kepribadian guru menunjukkan kemampuan personal yang mencerminkan kepribadian (1) mantap dan stabil yaitu memiliki konsistensi dalam bertindak sesuai norma hukum, norma sosial, dan etika yang berlaku; (2) dewasa yang berarti mempunyai kemandirian untuk bertindak sebagai pendidik 


\section{Jurnal Serunai Administrasi Pendidikan Vol 8, No. 2, Oktober 2019 e-ISSN 2620-9209}

dan memiliki etos kerja sebagai guru; (3) arif dan bijaksana yaitu tampilannya bermanfaat bagi peserta didik, sekolah dan masyarakat dengan menunjukkan keterbukaan dalam berpikir dan bertindak; (4) berwibawa yaitu perilaku guru yang disegani sehingga berpengaruh positif terhadap peserta didik; dan (5) memiliki akhlak mulia dan memiliki perilaku yang dapat diteladani oleh peserta didik, bertindak sesuai norma religius, jujur, ikhlas, dan suka menolong. Nilai kompetensi kepribadian dapat digunakan sebagai sumber kekuatan, inspirasi, motivasi, dan inovasi bagi peserta didiknya.

Sikap guru dalam memberikan bimbingan dan didikan kepada peserta didiknya sangat dipengaruhi oleh kepribadiannya. Alexander (1971) menyatakan "No one can be a genuine teacher unless he is himself actively sharing in the human attempt to understand men and their word". Secara tidak langsung, Alexander menyarankan agar guru dapat memahami kesulitan yang dihadapi oleh muridnya dalam belajar, dan kesulitan lain yang mengganggu dalam hidupnya.

Guru sebagai teladan bagi muridmuridnya harus memiliki sikap dan kepribadian utuh yang dapat dijadikan tokoh panutan idola dalam seluruh segi kehidupannya. Karenanya guru harus selalu berusaha memilih dan melakukan perbuatan yang positif agar dapat mengangkat citra baik dan kewibawaannya terutama di depan murid-muridnya. Kompetensi pribadi menurut Usman (2004) meliputi (1) kemampuan mengembangkan kepribadian, (2) kemampuan berinteraksi dan berkomunikasi, dan (3) kemampuan melaksanakan bimbingan dan penyuluhan. Kompetensi kepribadian terkait dengan penampilan sosok guru sebagai individu yang mempunyai kedisiplinan, berpenampilan baik, bertanggung jawab, memiliki komitmen, dan menjadi teladan (Sagala, 2009 : 33).

Kompetensi profesional berkaitan dengan bidang studi menurut Slamet PH (2006) terdiri dari Sub-Kompetensi : (1) memahami matapelajaran yang telah dipersiapkan untuk mengajar; (2) memahami standar kompetensi dan standar isi mata pelajaran yang tertera dalam Peraturan Menteri serta bahan ajar yang ada dalam kurikulum tingkat satuan pendidikan (KTSP); (3) memahami struktur, konsep dan metode keilmuan yang menaungi materi ajar; (4) memahami hubungan konsep antar matapelajaran terkait; dan (5) menerapkan konsep-konsep keilmuan dalam kehidupan sehari-hari. Peranan guru sangat menentukan keberhasilan proses pembelajaran guru yang digugu dan ditiru adalah suatu profesi yang mengutamakan intelektualitas, kepandaian kecerdasan, keahlian berkomunikasi, kebijaksanaan dan kesabaran tinggi. Tidak semua orang dapat menekuni profesi guru dengan baik. Karena jika seseorang tampak pandai dan cerdas bukan penentu keberhasilan orang tersebut menjadi guru.

Guru mempunyai kedudukan sebagai tenaga profesional pada jenjang pendidikan dasar, pendidikan menengah, dan pendidikan anak usia dini pada jalur pendidikan formal 
yang diangkat sesuai dengan peraturan perundang-undangan Profesional, dan profesional berarti melakukan sesuatu sebagai pekerjaan pokok sebagai profesi dan bukan sebagai pengisi waktu luang atau sebagai hoby belaka. Profesi berarti menyatakan secara publik dan dalam bahasa latin di sebut "profession" yang digunakan untuk menunjukkan pernyataan publik yang di buat oleh seseorang yang bermaksud menduduki suatu jabatan publik. Guru yang terjamin kualitasnya diyakini mampu melaksanakan tugas dan fungsinya dengan baik. Penjaminan mutu guru perlu dilakukan dan waktu ke waktu demi terselenggaranya layanan pembelajaran yang berkualitas (Sagala, 2009 : 40).

Kompetensi profesional menurut Usman (2004) meliputi : (1) penguasaan terhadap landasan kependidikan, dalam kompetensi ini termasuk : (a) memahami tujuan pendidikan, (b) mengetahui fungsi sekilah di masyarakat, (c) mengenal prinsip-prinsip psikologi pendidikan; (2) menguasai bahan pengajaran, artinya guru harus memahami dengan baik materi pelajaran yang diajarkan. Penguasaan terhadap materi pokok yang ada pada kurikulum maupun bahan pengayaan; (3) kemampuan menyusun program pengajaran, mencakup kemampuan menetapkan kompetensi belajar, mengembangkan bahan pelajaran dan mengembangkan strategi pembelajaran; dan (4) kemampuan menyusun perangkat penilaian hasil belajar dan proses pembelajaran. Kompetensi yang dimaksud adalah kompetensi profesional kependidikan. Kompetensi profesional mengacu pada perbuatan (performance) yang bersifat rasional dan memenuhi spesifikasi tertentu dalam melaksanakan tugas-tugas kependidikan. Mengenal perangkat kompetensi profesional biasanya dibedakan profil kompetensi yaitu mengacu kepada berbagai aspek kompetensi yang dimiliki seseorang tenaga profesional pendidikan dan spektrum kompetensi yaitu mengacu kepada variasi kualitatif dan kuantitatif. Perangkat kompetensi yang dimiliki oleh korps tenaga kependidikan yang dibutuhkan untuk mengoperasikan dan mengembangkan sistem pendidikan (Sagala, $2009: 41)$.

\section{Metode Penelitian}

Metode penelitian yang akan digunakan adalah metode deskriptif kuantitatif dengan jenis penelitian korelasional. Hal ini dirancang untuk memperoleh informasi tentang gejala pada saat penelitian dilakukan. Populasi dalam penelitian ini adalah seluruh guru SMP Negeri di Kecamatan Percut Sei Tuan yang berjumlah 308 Orang. sedangkan sampel berjumlah 96 orang. Data yang diperoleh dianalisis dengan menggunakan teknik statistik yakni uji persyaratan analisis data dan pengujian hipotesi. Dalam hal ini menggunakan bantuan komputer program SPSS 16.

\section{HASIL PENELITIAN DAN PEMBAHASAN}

Dari tabel deskriptif variabel kompetensi guru diketahui bahwa skor terendah adalah 14 dan yang tertinggi adalah 32. Rata-rata 23,14; 


\section{Jurnal Serunai Administrasi Pendidikan \\ Vol 8, No. 2, Oktober 2019 \\ e-ISSN 2620-9209}

simpangan baku 4,63; median 23; dan modus 22,36. Koefisien korelasi yang diperoleh untuk variabel kompetensi guru dengan kinerja guru adalah 0,603. Hal ini berarti $60,3 \%$ kinerja guru ditentukan oleh kompetensi guru. Korelasi ini bernilai posisitf, artinya kenaikan pada kompetensi guru akan diikuti oleh kenaikan pada kinerja guru. Korelasi ini dinyatakan signifikan ditandai dengan nilai sig pada output SPSS yang bernilai 0,000 dan berada di bawah $\alpha$ yaitu 0,05 .

Untuk menafsirkan koefisien korelasi tersebut digunakan kriteria penafsiran Guilford Emperical Rules (Somantri dan Muhidin, 2006 : 214) sebagai berikut :

$0,00-0.20=$ korelasi yang rendah sekali

$0,20-0,40=$ korelasi yang rendah tetapi ada

$0,40-0,70=$ korelasi yang sedang

$0,70-0,90=$ korelasi yang tinggi

$0,90-1,00=$ korelasi yang tinggi sekali

Berdasarkan kriteria tersebut, maka korelasi antara kompetensi guru dengan kinerja guru berada pada tingkat sedang, yaitu berada di antara 0,40 sampai 0,70 . Artinya kompetensi guru berhubungan dengan kinerja dalam hal ini kinerja guru, dimana dengan kompetensi guru yang baik maka dengan sendirinya akan meningkatkan kinerjanya. Temuan penelitian ini didukung dengan hasil penelitian Edy Suparno, 2006 yang meneliti Pengaruh Kompetensi, Motivasi Kerja, dan Kecerdasan Emosional Guru terhadap Kinerja Guru di SMP Negeri Se-Rayon Barat Kabupaten Sragen. Hasil penelitian ada pengaruh yang signifikan kompetensi guru terhadap kinerja guru di SMP Negeri se-Rayon Barat Kabupaten Sragen dapat dibuktikan kebenarannya. Hal tersebut ditunjukkan dengan hasil perhitungan $\mathrm{t}_{1}=4,788>\mathrm{t}_{\text {tabel }}=1,960$ pada taraf signifikansi $5 \%$. (http://etd.eprints.ums.ac.id).

Temuan penelitian menunjukkan bahwa ada hubungan yang signifikan antara kompetensi guru dengan kinerja guru sebesar 58,4\%. Temuan ini didukung pendapat Hadi (2009) kompetensi merupakan satu kesatuan yang utuh yang menggambarkan potensi, pengetahuan,keterampilan, dan sikap yang dinilai, yang terkait dengan profesi tertentu berkenaandengan bagian-bagian yang dapat diaktualisasikan dan diujudkan dalam bentuktindakan atau kinerja untuk menjalankan profesi tertentu. Menurut Spencer. L. \& Spencer. S, 1993 (dalaam Sinaga, R, 2010 : 25) mendefinisikan kompetensi sebagai kemampuan dari suatu karakteristik yang menonjol dari seorang individu yang berhubungan dengan kinerja efektif dalam suatu pekerjaan atau situasi.

\section{E. Penutup}

Berdasarkan data dan hasil analisis yang telah dipaparkan diatas, dapat ditarik kesimpulkan sebagai berikut: Terdapat hubungan yang signifikan antara kompetensi guru dengan kinerja guru. Hal ini mengindikasikan betapa pentingnya kompetensi guru dalam miningkatkan kinerja guru. Berdasarkan penemuan penelitian ini dapat disimpulkan bahwa hipotesis penelitian yang menyatakan ada hubungan antara kompetensi guru dengan kinerja guru dapat diterima.

Saran-saran yang disampaikan sehubungan dengan temuan penelitian ini adalah sebagai berikut: Kepada pengawas sekolah di Kecamatan 
Percut Sei Tuan agar lebih meningkatkan supervise terhadap guru terutama dalam hal mengahsilkan prakrsa dalam bekerja, senang dalam menjalankan tugasnya sebagai guru dan bersedia menerima terhadap setiap pembaharuan terkait dengan tugastugas sebagai guru. Kepada kepala sekolah agar lebih menekankan perlunya meningkatkan kompetensi bagi guru dalam rangka meningkatkan kinerja guru. Kepada Dinas Pendidikan Nasional Kabupaten Deli serdang agar memberi pengawasan yang ketat dan berkesinambungan kepada guru dengan mengacu kepada peraturan yang berlaku.

\section{DAFTAR PUSTAKA}

Amstrong, Michael. 1998. The art HRD, Managing People, Jakarta : Gramedia.

Edy Suparno. Pengaruh Kompetensi, Motivasi Kerja, dan Kecerdasan Emosional Guru terhadap Kinerja Guru di SMP Negeri Se-Rayon Barat Kabupaten Sragen. Tesis. Surakarta: Program Pascasarjana Universitas Muhammadiyah Surakarta, 2005.

Gibson, D. and Jon M.Ivancevich. 1990. Managemen terjemahan. Jakarta : Erlangga.

Rivai, Veithzal. 2005. Perpormance Appraisal. Jakarta : Raja Grafindo Parsada.

Sagala, 2007. Manajemen Strategik dalam Peningkatan Mutu Pendidikan. Bandung : Alfabeta.

2009. Kemampuan Profesional Guru dan Tenaga Kependidikan. Bandung Alfabeta.

Slamet, PH. 2006. Menuju Pengelolaan Pendidikan Berbasis Sekolah. Jakarta : Depdiknas.

Usman, Uzer. 1984. Menjadi Guru Profesional. Bandung : PT. Rosda Karya.
Wahyu Sumijo. 2007. Kepemimpinan Kepala Sekolah. Jakarta : Raja Grafindo Persada. 